\section{MERAYAKAN}

\section{ANUGERAH TUHAN}

Mengapa disebut anugerah Tuhan? Kita hidup bukan karena kekuatan dan kehebatan kita, melainkan oleh karena kebaikan dan kemurahan Tuhan yang ditandai dengan pengampunan melalui kematian Yesus di atas kayu salib. Kita melayani bukan karena keinginan manusia, tetapi oleh karena panggilan dan pengutusanNya untuk mewujudkan rencana-Nya dalam dunia ini. Kita dapat menghadapi dan melewati berbagai tantangan dan pergumulan serta perbedaan yang ada, oleh karena keteguhan iman yang diberikan Tuhan bagi kita sehingga tidak terombang-ambingkan, bahkan tetap berjalan bersama dalam harmoni. Akhirnya, kepada Tuhan hormat dan kemuliaan sampai selama-lamanya.

Melalui buku ini kita semakin memahami bahwa karya Tuhan dalam kehidupan kita, tidak dapat diselami oleh pikiran manusia, tetapi sungguh nyata dirasakan dan dinikmati. Mari merayakan anugerah Tuhan dengan penuh sukacita!

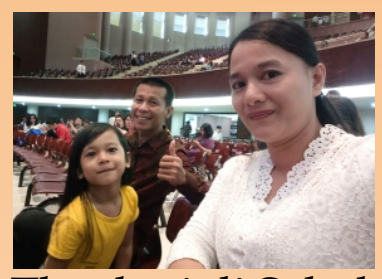

Pdt. Arif Yupiter Gulo, M.Th. Menyelesaikan program Sarjana Theologi di Sekolah Tinggi Theologi Injili Arastamar Jakarta (SETIA), tahun 2013. Kemudian, Program Magister

Theologi di Sekolah Tinggi Theologi Jaffray Jakarta, tahun 2016. Selain Dosen, ia juga merupakan Pendeta di BNKP (Banua Niha Keriso Protestan)

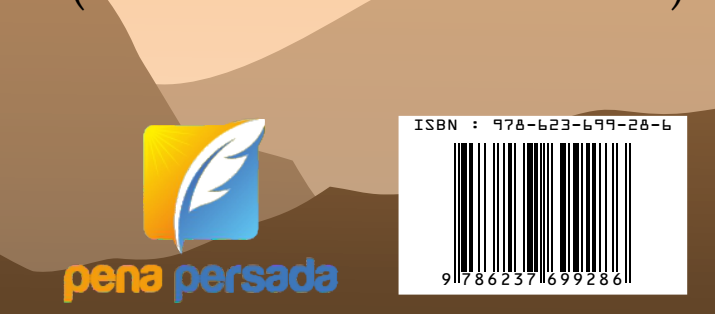

\section{MERAYAKAN}

\section{ANUGERAH TUHAN}
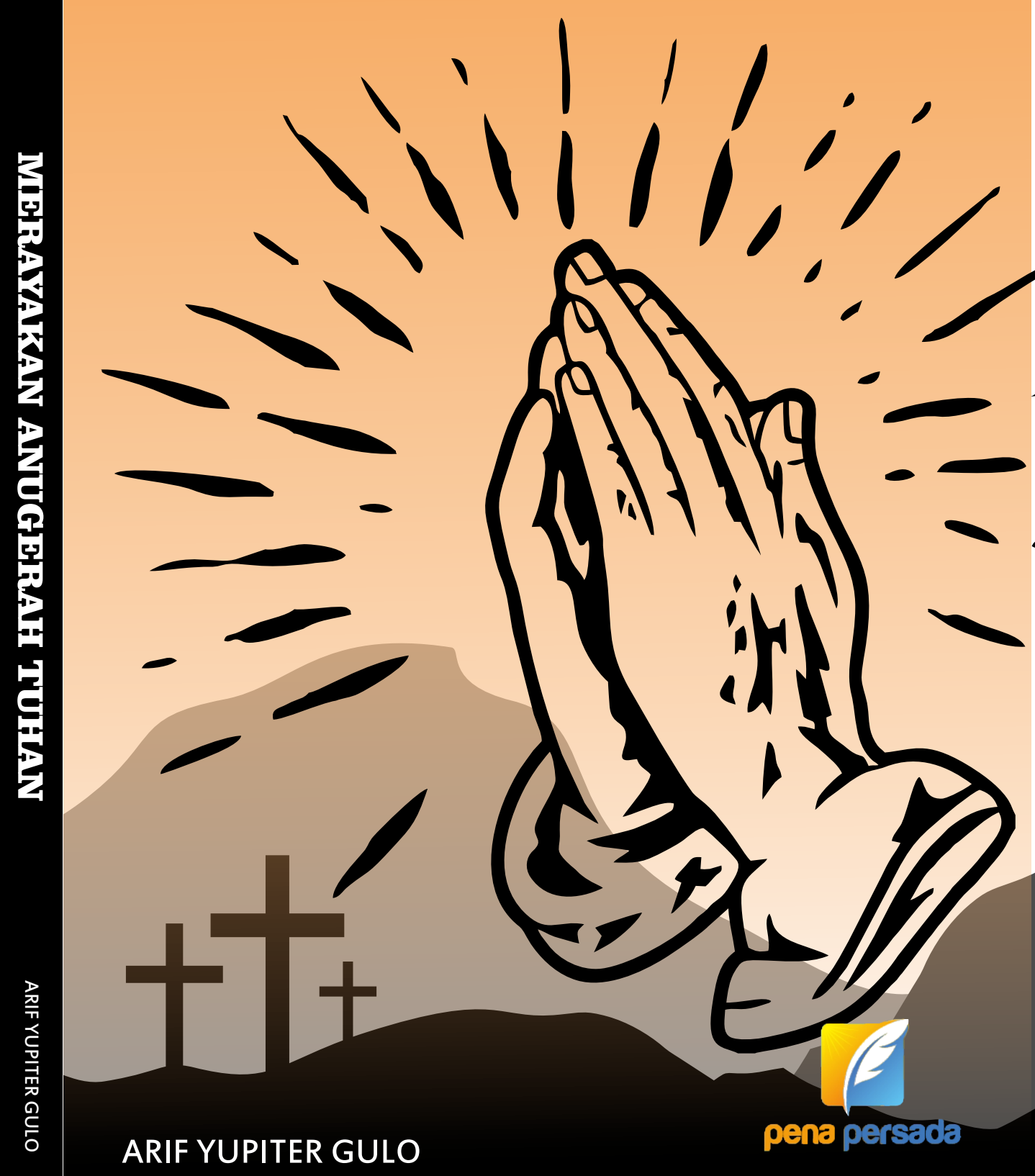


\title{
MERAYAKAN ANUGERAH TUHAN
}

\author{
Arif Yupiter Gulo
}

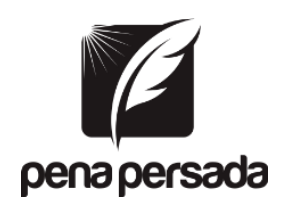

PENERBIT CV. PENA PERSADA 


\title{
MERAYAKAN ANUGERAH TUHAN
}

\author{
Penulis : \\ Arif Yupiter Gulo \\ ISBN : 978-623-7699-28-6 \\ Desain Sampul \\ Retnani Nur Briliant \\ Penata Letak \\ Fajar T. Septiono \\ Penerbit CV. Pena Persada \\ Redaksi : \\ Jl. Gerilya No.292 Purwokerto Selatan, Kab. Banyumas \\ Jawa Tengah \\ Email : penerbit.penapersada@gmail.com \\ Website : www.penapersada.com \\ Phone : 0857-2604-2979
}

Anggota IKAPI

All right reserved

Cetakan Pertama : 2020

Hak Cipta dilindungi oleh undang-undang.

Dilarang memperbanyak karya tulis ini dalam bentuk dan cara apapun tanpa izin dari penerbit. 


\section{KATA PENGANTAR}

Bersyukur kepada Tuhan oleh karena dapat menyelesaikan buku ini. Untuk itu penulis mengutip firman Tuhan berkata, "Dengan sepenuh hati aku mau bersyukur kepada-Mu, Tuhan, dan mewartakan karya-Mu yang mengagumkan (Mazmur 9:1)."

Buku ini merupakan kumpulam khotbah yang inspiratif dengan panggalian, pemaknaan dan penghayatan yang menekankan tentang pengampunan dari Tuhan disebabkan karena pertobatan dan perpalingan yang sungguh-sungguh. Selain itu, menguraikan tentang keterpanggilan untuk melayani dengan perlengkapan dengan kuasa kasih karunia dari Tuhan dalam mewujudkan rencana-Nya dalam dunia ini.

Bagian lainnya terkait dengan keteguhan iman untuk dapat menghadapi tantangan dan pergumulan baik secara internal dan eksternal sehingga tidak dapat terombang-ambingkan namun tetap teguh dan kokoh bahkan tetap terjaga kebersamaan dan keharmonisan yang akhirnya hati penuh dengan ucapan syukur kepada Tuhan dengan segala hormat dan kemuliaan-Nya.

Dalam bagian terakhir ini secara khusus saya ucapkan terima kasih kepada kedua kekasih hati yang mendampingi dan menguatkan sehingga selesai di rilis buku ini, yaitu istri tercinta Titi Murni Gulo, A. Md dan anakku yang kukasihi dengan segenap hatiku, Shine Oani Gulo. Melalui mereka berdua penulis merasakan banyaknya anugerah Tuhan yang tidak terhingga.

Ekspetasi dan doa penulis semoga melalui buku ini dapat meneguhkan pembaca yang budiman sehingga dapat memberkati, meneguhkan dan menguatkan iman kepada Tuhan.

Akhirnya, segala hormat dan kemuliaan hanya kepada Tuhan sekarang dan selama-selamanya. Amin.

Penulis. 


\section{Daftar Isi}

1. Berubah karena Anugerah-Nya ................................................ 1

2. Berbalik dari Tegar Tengkuk ................................................... 6

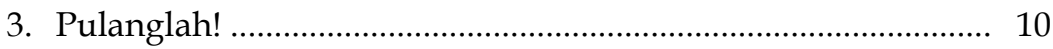

4. Kembali ke Jalan yang Benar ...................................................... 15

5. Harapan tentang Pembebasan.................................................. 20

6. Hidup Baru dalam Damai....................................................... 24

7. Melayani Sambil Berjaga-jaga .................................................. 29

8. Melayani dengan Kasih.............................................................. 33

9. Perlengkapan Melayani............................................................ 39

10. Kejatuhan dan Pengurapan Raja ................................................ 44

11. Resiko dalam Melayani ....................................................... 49

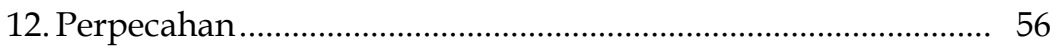

13. Berkat Ditengah Pergumulan ................................................... 60

14. Kasih Tuhan Disaat Kehilangan Harapan ................................. 65

15. Fenomena Hari Tuhan.......................................................... 72

16. Waspadalah: Kedatangan-Nya dan Kesudahan Dunia ............ 77

17. Kemana Harus Mengadu? .......................................................... 83

18. Hidup Berkenan kepada Tuhan ................................................ 87

19. Tunduk dan Mengasihi ................................................................ 93

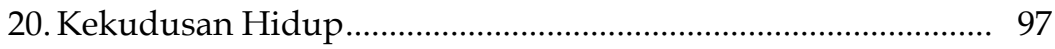

21. Kebahagiaan Sejati ................................................................. 101

22. Kehadiran-Nya Bagi yang Percaya .......................................... 106

23. Kehadiran-Nya dalam Dunia ................................................... 110

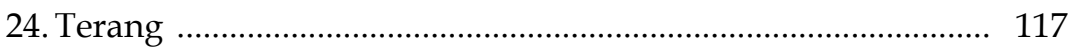

25. Tuhan Tempat yang Tidak Salah .......................................... 122

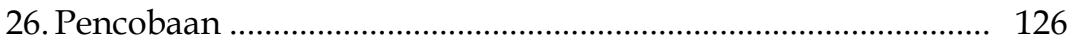

27. What is Your Life? ........................................................... 130

28. Merendahkan Hati lebih Terhormat........................................... 134

29. Membangun Bait Suci......................................................... 138

30. Makna Hidup yang Sesungguhnya ......................................... 142

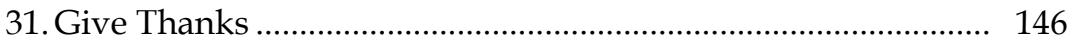




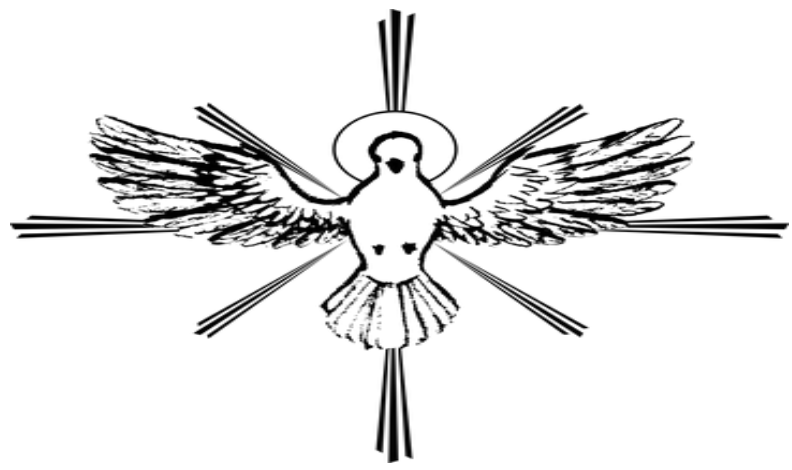

Berubah

Karena Anugerah-Nya

2 Korintus 5:16-21

Setiap manusia pasti menginginkan perubahan yang ditandai dengan berubah (keadaan); peralihan; pertukaran, baik secara lahiriah maupun batiniah. Untuk itu, maka Paulus berkata, "Jangan kamu serupa dengan dunia ini, tetapi berubah oleh pembaharuan budimu,...(Roma 12:2)." Seruan Paulus ini terkait dengan perubahan dari kehidupan lama menjadi hidup baru. Oleh karena itu, apa upaya yang ditempuh untuk dapat berubah dari kehidupan lama menjadi hidup baru? Mari kita simak kisah berikut, Ada cerita tentang seseorang yang pulang acara camping di pantai Sindak Sundak, Gunung Kidul, tanpa sadar ia salah arah. Di sebuah pertigaan, seharusnya dia belok kanan untuk kembali ke Jogja tetapi malah belok kiri. Setelah lebih setengah jam memacu sepeda motor, orang itu baru tersadar kalau sudah salah arah. Di tengah perjalanan kembali ke arah yang benar, orang itu merenungkan kejadian tersebut, begitulah yang terjadi kalau orang tidak segera bertobat ketika melakukan dosa. Semakin lama ia 'salah arah' dan tidak segera bertobat, semakin sulit baginya untuk kembali kepada Tuhan.

Cerita ini menjelaskan tentang kesadaran yang mendalam melalui karya Roh Kudus sehingga dapat berbalik dan berubah menjadi manusia baru. Dengan demikian dapat dikatakan bahwa 
mengalami perubahan merupakan anugerah dari Tuhan (By Grace of God). Itu sebabnya Paulus menegaskan bahwa, "Sebab karena kasih karunia kamu diselamatkan oleh iman; itu bukan hasil usahamu, tetapi pemberian Allah." Terkait dengan itu, Inilah yang dijelaskan dalam nas 2 Korintus 5:16-21 ini yang akan diuraikan secara spesifik.

\section{a. Tidak Menilai dengan Ukuran Manusia (ay. 16)}

Sebelum bertobat, maka Paulus memiliki hidup yang kelam dengan dikuasai oleh kedagingan dan kegelapan sehingga tindakan dan perbuatannya sangat menyedihkan dengan mencelakakan pengikut Tuhan. Namun setelah bertemu dengan Yesus dalam perjalanan di Damsyik (Kisah Para Rasul 9:1-20; 22:4), maka terjadi perubahan dalam diri Paulus sehingga menyatakan bahwa, Kami tidak lagi menilai seorang juga pun menurut ukuran manusia. Bahkan ditegaskan, Dan jika kami pernah menilai Kristus menurut ukuran manusia, sekarang kami tidak lagi menilai-Nya demikian. Hal ini menunjukkan bahwa Paulus telah mengalami pertobatan yang luar biasa. Apa yang merupakan keuntungan baginya sebelumnya, maka semua itu ditanggalkan atau ditinggalkan. Paulus menatap masa depan yang cemerlang dengan harapan yang tidak pernah sia-sia. Bahkan Paulus menjadi pelayan Tuhan yang militan dalam memperkenalkan dan menyampaikan keselamatan bagi orang lain dengan tidak takut dan gentar, kendati berbagai tantangan yang terbentang.

Oleh karena itu, Paulus menjadi inspirasi bagi kita dalam memaknai pertobatan kita, yang ditandai dengan tidak menggosipkan orang lain. Tidak menganggap remeh dan rendah siapa pun, tetapi menghargai dan menghormatinya. Dan menerima kelemahan dan kekurangan kita sebab tidak ada manusia yang sempurna. Bahkan, menerima kelemahan dan kekurangan sesama bukan dengan mencemooh bahkan menganggap rendah atau menyepelekan. Selain itu, kita memiliki kesungguhan untuk mempersembahkan hidup kita untuk dipakai sebagai instrument dalam melebarkan dan mewujudkan kerajaan-Nya di dalam dunia ini. Inilah 
pertobatan yang sejati dengan perubahan yang signifikan dengan ditandai oleh cara hidup yang berkenan kepada Tuhan.

\section{b. Menjadi Manusia Baru (ay. 17-19)}

Manusia sudah jatuh dalam dosa. Untuk itu, upah dosa adalah maut (Roma 6:23). Namun, karena begitu besar kasih Allah akan dunia ini, sehingga Ia mengaruniakan anak-Nya yang tunggal, supaya setiap orang yang percaya kepada-Nya tidak binasa, melainkan beroleh hidup yang kekal (Yohanes 3:16). Paulus telah merasakan Kasih karunia tersebut, sehingga dalam ayat 18 dinyatakan, "Dan semuanya ini dari Allah." Pernyataan tentang semua dari Allah ini, yang mengacu kepada pembebasan dan pengampunan yang telah diterima dan dirasakan oleh Paulus sehingga pada akhirnya Paulus telah menjadi manusia baru yang lama sudah berlalu yang baru sudah datang. Hal ini yang disebut adalah kelahiran baru karena membuka hati menerima Yesus dan percaya dengan sungguh-sungguh. Itu sebabnya, ditegaskan dalam ayat 19 bahwa, Allah mendamaikan dunia dengan diriNya tanpa memperhitungkan pelanggaran. Terkait dengan ini, maka dalam Yesaya 1:18 dinyatakan, Sekalipun dosamu merah seperti kirmizi, akan menjadi putih seperti salju; sekalipun berwarna merah seperti kain kesumba, akan menjadi putih seperti bulu domba.

Dengan demikian, apa indikator menjadi ciptaan baru? Hal ini terkait dengan kasih yang dimiliki dengan tidak hanya untuk dirinya sendiri, tetapi diimplementasikan kepada Tuhan dan kepada sesama bahkan kepada musuh sekalipun. Tidak kehilangan sukacita dan damai sejahtera di saat merasakan kesulitan, kesusahan dan melimpah sukacita, damai sejahtera di dalam Tuhan di kala merasakan kebahagiaan tanpa melupakan Tuhan. Memiliki kesabaran dalam pengharapan dan tidak kehilangan kesabaran dalam menghadapi penganiayaan. Melimpah kemurahan di saat berkat sudah diterima untuk menjadi berkat bagi orang lain. Menunjukkan kebaikan kepada siapa pun tanpa terkecuali. 
Memiliki kesetiaan dengan tidak ada batasnya sampai kesudahannya. Menampakkan kelemahlembutan kepada siapa pun dengan tidak menunjukkan kekerasan dan kehebatan serta kekuatannya. Bahkan, dapat menguasai diri dari kegelapan dan kedagingan, maka menjadi pemenang di dalam Tuhan. Itu sebabnya ditegaskan bahwa "Tetapi buahbuah Roh ialah: kasih, sukacita, damai sejahtera, kesabaran, kemurahan, kebaikan, kesetiaan, kelemahlembutan, penguasaan diri. Tidak ada hukum yang menentang hal-hal itu (Galatia 5:22).

\section{c. Utusan Tuhan dan Kerinduan untuk Damai (ay. 20-21)}

Orang yang sudah bertobat maka harus berbuah dalam panggilan dan pengutusan dari Allah untuk melayani. Paulus menegaskan, "Jadi kami ini adalah utusan-utusan Kristus,...(ay. 20)." Paulus memperkenalkan dirinya sebagai pelayan Tuhan dengan mengemban tugas yang begitu berharga dan penting. Bagi Paulus, Tiada pekerjaan yang lebih menyenangkan dan mulia, selain melayani pekerjaanNya. Dalam 2 Timotius 2:21 ditegaskan bahwa, Jika seorang menyucikan dirinya dari hal-hal jahat, ia akan menjadi perabot rumah untuk maksud yang mulia, ia dikuduskan, dipandang layak untuk dipakai tuannya dan disediakan untuk setiap pekerjaan yang mulia.

Oleh karena itu, tugas yang diemban itu dengan menyuarakan perdamaian yang secara eksplisit dijelaskan, "Berilah dirimu didamaikan dengan Allah (ay. 20)." Ungkapan "Berilah dirimu" merupakan seruan yang sangat serius. Itu sebabnya diharapkan respon yang sungguhsungguh untuk mau berdamai dengan Allah yang masih menutup pintu hatinya untuk tidak menerima keselamatan dan kehidupan kekal. Namun, dengan membuka hati menerima seruan Paulus, maka mendapatkan kasih karunia melalui Yesus yang telah berkorban di atas kayu salib untuk menebus dosa-dosa manusia. Untuk itu, maka Paulus mengatakan bahwa, "Dia yang tidak mengenal dosa telah 
dibuat-Nya menjadi dosa karena kita, supaya dalam Dia kita dibenarkan oleh Allah (ay. 20)."

Dengan demikian, sudahkah kita membuka hati untuk menjadi instrument dari Tuhan untuk menyuarakan kedamaian? Sebab Tuhan berkata, Berbahagialah orang yang membawa damai, karena mereka akan disebut anak-anak Allah (Matius 5:9). Untuk itu maka kedamaian menggema antara Tuhan dengan manusia, dan manusia dengan sesamanya bahkan dengan alam semesta. 


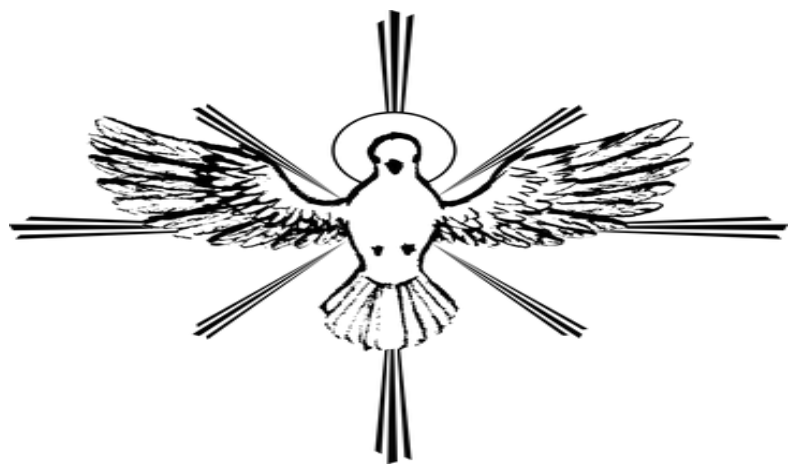

Berbalik dari Tegar Tengkuk

Keluaran 33:1-6

Tuhan tidak pernah berkekurangan atau kehabisan kekuatan dalam menolong umat-Nya. Bahkan kekuatan-Nya tidak ada bandingnya di alam semesta ini sebab Dia adalah maha pencipta. Kuasa-Nya ini telah dibuktikan ketika memanggil dan mengutus Musa untuk membebaskan dan mengeluarkan bangsa Israel dari Mesir untuk membawa ke tanah perjanjian yaitu tanah Kanaan yang penuh dengan madu dan susu sesuai dengan janji-Nya kepada Abraham, Ishak dan Yakub.

Dalam perjalanan mereka menuju tanah Kanaan, Tuhan memberikan semua kebutuhan mereka dengan sangat melimpah. Namun, bangsa Israel selalu berkekurangan sehingga menyalahkan Musa, bahkan menyalahkan Tuhan serta melakukan tindakan dan perbuatan yang menyimpang. Itu sebabnya dalam Keluaran 33:1-6, maka Tuhan menyebut mereka sebagai bangsa yang tegar tengkuk sehingga Tuhan tidak berjalan ditengah-tengah mereka, melainkan hanya mengutus malaikat berjalan di depan mereka saja. Kendati demikian, Tuhan memberikan kesempatan untuk bertobat dan berpaling kepada-Nya. 


\section{a. Tegar Tengkuk (ay. 1-3)}

Bangsa Israel disebut bangsa yang tegar tengkuk (ay. 3). Apa sesungguhnya tegar tengkuk? Tegar tengkuk adalah keras kepala, tidak mau menurut, tidak taat, tidak setia, dan tidak patuh. Istilah tegar tengkuk digunakan dalam Alkitab untuk menyatakan kebandelan, kedegilan manusia yang tidak meresponi tuntunan Tuhan.

Bangsa Israel disebut sebagai bangsa yang tegar tengkuk disebabkan ketika Musa tidak bersama-sama dengan mereka untuk bertemu dengan Tuhan di gunung Sinai selama 40 hari 40 malam. Maka, dalam pasal 32 dijelaskan bahwa bangsa Israel membuat bagi mereka anak lembu emas dari perhiasan mereka. Setelah dipahat, maka mereka sembah dan memberikan korban persembahan serta bersukacita. Tindakan dan perbuatan mereka ini diketahui oleh Tuhan maka Tuhan menyuruh Musa untuk kembali di tengah-tengah bangsa Israel dan memberitahukan tentang tindakan dan perbuatan mereka itu yang telah memicu kemarahan Tuhan.

Dewasa ini, kita tidak mengukir atau membuat patung lagi untuk disembah tetapi terdapat umat Tuhan yang memberhalalkan harta, jabatan, dan kekuasaannya. Memiliki kekayaan dan jabatan serta kekuasan tidak berkesalahan sebab dalam Alkitab hal itu dibenarkan oleh Tuhan. Namun, bukan itu yang mengendalikan dan mengatur hidup kita. Bahkan, bukan itu yang utama dalam setiap tujuan hidup kita. Alkitab menegaskan bahwa, "Tetapi carilah dahulu kerajaan Allah dan kebenaran-Nya, maka semuanya itu akan ditambahkan kepadamu (Matius 6:33)."

Oleh karena itu, mari kita melakukan transformasi hidup untuk tidak menyembah yang bukan allah sesungguhhnya sebab Tuhan telah melarangnya, dalam Keluaran 20:3-5 dikatakan bahwa, "Jangan ada padamu allah lain dihadapan$\mathrm{Ku}$. Jangan membuat bagimu patung yang menyerupai apa pun yang ada di langit di atas, atau yang ada di bumi di bawah, atau yang ada di dalam air di bawah bumi. Jangan sujud menyembah kepadanya atau beribadah kepadanya, sebab Aku, Tuhan, Allahmu, adalah Allah yang cemburu, yang 
membalaskan kesalahan bapa kepada anak-anaknya, kepada keturunan yang ketiga dan keempat dari orang-orang yang membenci Aku."

Dengan demikian, larangan ini harus dijunjung tinggi dan dihargai serta dihormati dengan menjauhinya, maka kita akan disebut anak Allah. Galatia 4:7 menegaskan, "Jadi kamu bukan lagi hamba, melainkan anak; jikalau kamu anak, maka kamu juga adalah ahli-ahli waris, oleh Allah."

\section{b. Tuhan tidak Berada di Tengah-tengah Umat-Nya (ay. 3, 5)}

Konsekuensi dari setiap kesalahan pasti ada. Itu sebabnya, sebagai akibat dari perbuatan bangsa Israel adalah Tuhan tidak berada ditengah-ditengah mereka. Namun, hanya menyuruh malaikat berjalan di depan mereka sebagai upaya untuk menghalau bangsa lain untuk tidak membinasakan mereka. Selain itu, Tuhan tidak berada di tengah-tengah mereka supaya tidak membinasakan mereka di dalam perjalanan. Hal ini menunjukkan bahwa Tuhan masih mengasihi dengan cara menyertai dalam perjalanan. Namun, bukan berarti bahwa kemarahan Tuhan sudah redam, justru Tuhan tetap konsisten untuk memberikan hukuman kepada bangsa Israel jika seandainya mereka tidak berubah dan berpaling kepada-Nya. Jika mereka berubah dan bertobat maka akan mendapatkan kasih karunia dari Tuhan.

Oleh karena itu, hal ini menjadi peringatan keras bagi kita, dengan upaya untuk menjaga dan merawat hubungan kita dengan Tuhan supaya tidak ada jurang pemisah yang mengakibatkan berkat Tuhan tidak tercurah bagi kita, tetapi konsisten dan komitmen untuk mengikut Tuhan yang ditandai dengan hidup tidak tercela, tidak tercemar bahkan tidak serupa dengan dunia ini. Namun, hidup dengan pembaharuan budi, beribadah dan mengasihi Tuhan dengan sungguh-sungguh dan segenap hati. Dengan demikian yang pada akhirnya, sekalipun kita berjalan di dalam kekelaman maka Tuhan selalu menjaga dan bersama-sama dengan kita untuk memberkati, meneguhkan dan memelihara, baik keluarga kita, usaha dan pekerjaan kita. 


\section{c. Berkabung sebagai Upaya Penyesalan (ay. 4-6)}

Tuhan menyuruh Musa untuk menyampaikan rencanaNya bagi bangsa Israel terkait dengan hukuman yang akan menimpa mereka yang merupakan suatu kenyataan, sebab hal itu telah dibuktikan di dalam pasal 32 yaitu, mereka saling membunuh dan membantai antara saudara dan sesama, sehingga atas kejadian itu mengakibatkan kira-kira tiga ribu orang yang tewas, maka dalam hal ini, bangsa Israel harus ada keseriusan untuk menanggapi rencana Tuhan tersebut.

Tatkala bangsa Israel mendengar berita tersebut maka mereka, "Berkabung" yang ditandai dengan, "Tidak ada seorang pun yang memakai perhiasan." Berkabung menandakan bahwa mereka berdukacita atas peristiwa yang akan menimpa mereka. Sikap perkabungan ini, merupakan sikap yang terpuji bahkan dapat dikatakan sebagai upaya untuk berubah dan bertobat. Sebab, perkabungan yang sama pernah dialami oleh bangsa Niniwe setelah mereka menerima berita penghukuman atas mereka yang disampaikan oleh Yunus (Yunus 3:5-8). Bangsa Niniwe berkabung untuk memohon belas kasihan dari Tuhan sehingga bangsa Niniwe mendapatkan kasih karunia yang pada gilirannya mereka tidak dibinasakan.

Sikap untuk berkabung yang perlu diperhatikan adalah kesungguhan dari dalam hati. Jika berkabung dengan simbolis atau hanya formalitas, maka sia-sia dan hampa sebab hanya orang yang sungguh-sungguh menyesal mendapat kasih karunia. Tuhan berkata, "Sekalipun dosamu merah seperti kirmizi, akan menjadi putih seperti salju; sekalipun berwarna merah seperti kain kesumba, akan menjadi putih seperti bulu domba (Yesaya 1:18)." Namun, "Jika kita mengaku dosa kita, maka Ia adalah setia dan adil, sehingga Ia akan mengampuni segala dosa kita dan menyucikan kita dari segala kejahatan kita (I Yohanes 1:9)." Bahkan, "Karena dengan hati orang percaya dan dibenarkan, dan dengan mulut orang mengaku dan diselamatkan (Roma 10:10)." 


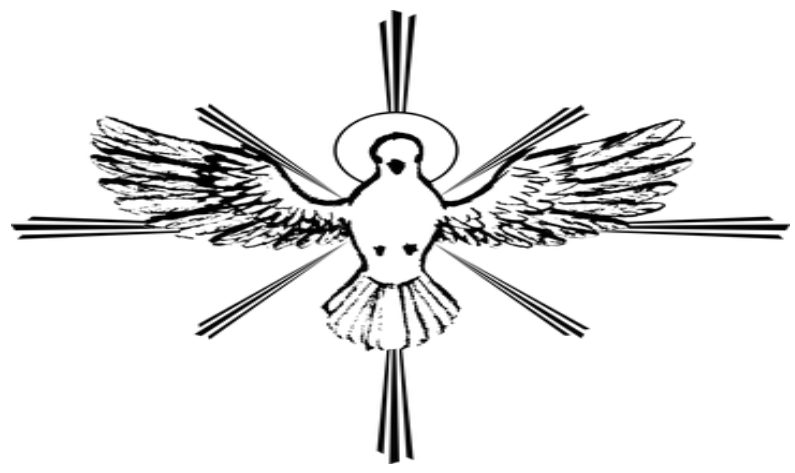

\section{Pulanglah!}

Yesaya 45:18-25

Ibarat seorang anak yang membangkang dan meninggalkan orangtuanya dengan begitu lama sehingga hidupnya berantakan dan tidak bermakna dengan menuai kesiasiaan sebab tidak ada yang mengingatkan dan menasehati serta yang memberikan kasih sayang. Sudah lama meninggalkan rumah, sebagai orangtua yang baik mengharapkan anaknya untuk pulang ke rumah supaya berkumpul kembali, dengan meminta kepada anaknya untuk memohon maaf dengan sungguh-sungguh.

Kisah ini menyerupai kehidupan bangsa Israel di mana mereka meninggalkan Tuhan dengan menyembah allah lain. Pada hal Tuhan sudah begitu baik dalam menolong dan memberkati mereka. Namun, mereka tetap membangkang dan memberontak serta melawan Tuhan. Oleh karena itu, Tuhan mengutus Yesaya untuk menaburkan dan menyampaikan pesan kepada mereka supaya mereka bertobat dan berpaling kepadaNya. Untuk itu, mengapa Tuhan mengajak bangsa Israel untuk kembali kepada-Nya? Dan bagaimana sikap bangsa Israel, tatkala kembali kepada Tuhan? Inilah yang diuraikan dalam nas Yesaya 45:18-45 ini. 


\section{a. Hanya Dia Sebagai Allah yang Disembah (ay. 18)}

Bangsa Israel tidak memiliki kesungguhan dan keseriusan dalam menyembah Tuhan. Menyembah Tuhan artinya bertekuk lutut dan memuja serta memuji Dia yang mengacu kepada sikap untuk menyenangkan dan memuliakan Tuhan dengan segenap hati. Untuk itu, mengapa menyembah Tuhan? Dalam ayat 18 ditegaskan bahwa, Tuhan menciptakan, menjadikan serta menegakkan bumi dari yang tidak ada menjadi ada (ex nihilo). Tuhan menciptakan dan menjadikan serta menegakkan bumi bukan untuk kosong tetapi berguna untuk ciptaan yang lain. Bahkan, ditekankan bahwa, Akulah Tuhan dan tidak ada yang lain (ay. 18). Oleh karena itu, Berilah kepada Tuhan kemuliaan nama-Nya, sujudlah kepada Tuhan dengan berhiaskan kekudusan! (Mazmur 29:2).

Dengan demikian, maka seruan ini sangat relevan bagi kita. Itu sebabnya marilah kita menyembah Tuhan dengan segenap hati kita. Pemazmur menyerukan bahwa, "Beribadahlah kepada Tuhan dengan takut dan ciumlah kakiNya dengan gemetar (Mazmur 2:11)." Artinya bahwa ada kesungguhan dan keseriusan bila berada di hadapan Tuhan dengan menjunjung tinggi perintah-Nya bukan dengan melanggar dan mengabaikannya. Biarlah Tuhan yang ditinggikan dan dimuliakan karena kuasa-Nya yang tidak terbantahkan dan tidak terbatas. Jadi, karena kita menerima kerajaan yang tidak tergoncangkan, marilah kita mengucap syukur dan beribadah kepada Allah menurut cara yang berkenan kepada-Nya, dengan hormat dan takut (Ibrani 12:28).

\section{b. Tidak Pernah Sia-sia yang Mencari Tuhan (ay. 19)}

Mencari Tuhan berbeda dengan mencari harta karun, disebabkan karena Tuhan tidak pernah tersembunyi atau menyembunyikan diri, bahkan perkataan dan ungkapan-Nya jelas disingkapkan dalam ayat 19 bahwa, "Tidak pernah Aku berkata dengan sembunyi atau di tempat bumi yang gelap." Artinya, Tuhan selalu ada dalam ruang yang terbuka untuk 
umat-Nya. Bahkan, Dia selalu ada dalam setiap kesempatan bagi umat-Nya yang mencari Dia, sebab Dia ada dimanamana tanpa dibatasi ruang dan waktu (Band. Amsal 15:3).

Oleh karena itu, dengan sungguh-sungguh mencari Tuhan, maka mendapatkan kelegaan, sesuai dengan janji-Nya bahwa, Marilah kepada-Ku, semua yang letih lesu dan berbeban berat, Aku akan memberikan kelegaan kepadamu (Matius 11:28). Akhirnya, orang yang menabur dengan mencucurkan air mata, akan menuai dengan bersorak-sorai. Orang yang berjalan maju dengan menangis sambil menabur benih, pasti pulang dengan sorak-sorai sambil membawa berkas-berkasnya (Mazmur 156:5-6). Untuk itu, orang yang mencari Tuhan tidak akan pernah sia-sia, sebab Tuhan memberikan penghiburan, kekuatan, bahkan memberikan keteguhan iman.

\section{c. Panggilan untuk Bersekutu kepada Tuhan (ay. 20-21)}

Lebih baik bersekutu kepada Tuhan dari pada berkumpul dengan pencemooh (Band. Mazmur 1:1). Bersekutu kepada Tuhan yang ditandai dengan keinginan dan kerinduan yang sungguh-sungguh, bahkan dengan segala kerendahan hati. Itu sebabnya dalam ayat 20 ditegaskan, "Berhimpunlah, datanglah, tampilah bersama-sama." Alasan mengapa berhimpun kepada Tuhan dengan jelas dikatakan bahwa, tiada pengetahuan bagi orang yang mengarak patung kayu dan berdoa kepada allah yang tidak menyelamatkan (ay. 20)." Tetapi, apabila kepada Tuhan mendapatkan pengetahuan dan wawasan rohani yang begitu tinggi dan sangat dalam, bahkan memperoleh hidup yang kekal. Paulus menegaskan dalam kitab Roma 12:1 dinyatakan, Karena itu, saudara-saudara, demi kemurahan Allah aku menasehatkan kamu, supaya kamu mempersembahkan tubuhmu sebagai persembahan yang hidup, yang kudus dan yang berkenan kepada Allah: itu adalah ibadahmu yang sejati.

Oleh karena itu, Tuhan mengajak kita untuk bersekutu kepada-Nya tanpa menyia-nyiakannya, sebab dapat meneguhkan dan menguatkan kita, apalagi dalam 
persekutuan tersebut, firman Tuhan ditaburkan untuk mengajar kita bahkan memperbaiki kesalahan kita supaya hidup kita lebih baik dan berguna bagi sesama. Itu sebabnya, dalam Ibrani 10:25 dinyatakan, "Janganlah kita menjauhi diri dari pertemuan-pertemuan ibadah kita, seperti dibiasakan oleh beberapa orang, tetapi marilah kita saling menasehati, dan semakin giat melakukannya menjelang hari Tuhan yang mendekat."

\section{d. Penyerahan Diri yang Sungguh-sungguh (ay. 22-25)}

Penyerahan diri kepada Tuhan merupakan seruan yang begitu serius dengan ungkapan, "Berpalinglah." Bahkan diteruskan dengan kalimat, "Biarkanlah dirimu diselamatkan." Seruan ini menunjukkan bahwa jangan terus menerus hidup dalam kegelapan yang akan membinasakan tetapi berubah dan bertobat. Dalam Matius 4:17 menyatakan, "Bertobatlah sebab kerajaan Allah sudah dekat." Hal ini merupakan panggilan untuk menyerahkan diri dengan sungguh-sungguh sehingga menjadi ciptaan baru (the new human). Manusia baru yang merujuk kepada kelahiran baru (the new birth), disebabkan karena pengenalan akan Yesus yang menghasilkan pertobatan dan perubahan. Itu sebabnya dalam ay. 25 dikatakan, "Tetapi seluruh keturunan Israel akan nyata benar dan akan bermegah di dalam Tuhan." Tentu, bermegah di dalam Tuhan yang mengacu kepada kasih karunia tentang mahkota kehidupan yang kekal.

Paulus menjadi inspirasi bagi umat Tuhan terkait dengan penyerahan diri yang benar dari penganiaya umat Tuhan menjadi pelayan yang militan demi Injil Kristus. Demikian juga kita harus menyerahkan diri kepada Tuhan untuk dibentuk menjadi murid-Nya dan pengikut-Nya yang benar sehingga berbuah dengan iman. Menyerahkan diri kepada Tuhan tanpa menoleh ke belakang, sebab orang yang menoleh kebelakang untuk kembali kepada kehidupan lama tidak layak dalam kerajaan Allah (Lukas 9:62). Menyerahkan diri dengan komitmen dan konsisten. Itu sebabnya, sepenggal lagu mengatakan, "Mengikut Kristus adalah keputusanku." 
Kita telah mengambil keputusan untuk mengikut Yesus maka kita harus berkomitmen terus menerus. Ini namanya, "Hendaklah engkau setia sampai mati maka Aku mengaruniakan mahkota kehidupan kepadamu (Wahyu 2:10b)." 